foot skin defects. Zhongguo Gu Shang (China Journal of Orthopaedics and Traumatology). 2013;26(8):634-636.

6. Hagurov R. F., Aleksandrov A. V., Rybchenok V. V., Samorukova N. N., Vel'skaya Yu. I. [et al.] Primenenie metoda ballonnoj dermatenzii v detskoj rekonstruktivno-plasticheskoj hirurgii. Vestnik Rossijskogo gosudarstvennogo medicinskogo universiteta. - Bulletin of the Russian State Medical University. 2016;5:34-38.

7. Aboelatta Y. A., Elshahm A., Saleh M. A., Kamel I. H. Aly H. M. Intraoperative and delayed wound approximation in closure of skin defects in different areas. J. Wound Care. 2015;24(12):600-605.
8. Katzengold R., Topaz M., Gefen A. Tissue loads applied by a novel medical device for closing large wounds. J. Tissue Viability. 2016;25(1):32-40.

9. Pyatakov S. N., Krivec D. V., Agadzhanjan D. Z. Sistema dlja lechenija obshirnyh ranevyh defektov - System for the treatment of extensive wound defects. Patent Russian Federation. № 117285, 2012.

10. Pyatakov S. N., Agadzhanjan D. Z., Fedosov S. R. Prisposoblenie dlja dermatenzii obshirnyh ranevyh poverhnostej. Patent Russian Federation. № 113464, 2012.

About authors:

Pyatakov Stanislav Nikolaevich, MD, CMSc, Associate Professor of the Department of Surgery № 1; tel.: +79184755575, e-mail: spyatakov@inbox.ru

Porkhanov Vladimir Alekseevich, Academician of the Russian Academy of Sciences, MD, DMSc, Chief Doctor; tel.: +78612529558; e-mail: kkb1@mail.ru

Baryshev Aleksandr Gennadievich, DMSc, Head of the Department of Surgery № 1; tel.: +79882478891; e-mail: a.barishev@icloud.com

Pyatakova Svetlana Nikolaevna, MD, Deputy Chief Physician for Organizational and Methodological Work, Surgeon;

tel.: +79182430300; e-mail: s_pyatakova@inbox.ru

Bardin Sergey Aleksandrovich, Assistant of the Department of Surgery № 1; tel.: +79184339666; e-mail: 00@bk.ru

Suzdaltsev Igor Vladimirovich, MD, DMSc, Professor Head of the Department of Faculty Surgery;

tel.: +79624492125; e-mail: suzdalsev@yandex.ru

(c) Group of authors, 2018

UDC 617.576-089.844

DOI - https://doi.org/10.14300/mnnc.2018.13083

ISSN - 2073-8137

\title{
TREATMENT OF OPEN INJURIES OF THE HAND IN CHILDREN
}

\author{
Gordienko I. I. ${ }^{1,2}$, Tsap N. A. ${ }^{1,2}$, Sosnovskich A. K. ${ }^{2}$, Borisov S. A. ${ }^{1}$ \\ ${ }^{1}$ Ural State Medical University, Yekaterinburg, Russian Federation \\ 2 Children's City Clinical Hospital № 9, Yekaterinburg, Russian Federation
}

\section{АЕЧЕНИЕ ОТКРЫТЫХ ПОВРЕЖАЕНИЙ КИСТИ У АЕТЕЙ}

\author{
И. И. Гораиенко ${ }^{1,2}$, Н. А. Цап ${ }^{1,2}$, А. К. Сосновских ${ }^{2}$, С. А. Борисов ${ }^{1}$ \\ 1 Уральский госуАарственный меАицинский университет, Екатеринбург, \\ Российская ФеАерация \\ 2 Аетская городская кАиническая больница № 9, Екатеринбург, \\ Российская ФеАерация
}

Injuries of the hand in children and adults occupy a special place in the structure of injuries of the musculoskeletal system. For a two-year period, 70 children with open bruises were treated. Analysis of the results of treatment shows that in the operative treatment of open injuries of the brush, priority should be given to the maximum organ-preserving tactics. There should be a single algorithm for prescribing antibacterial drugs in perioperative management of open hand injuries in children.

Keywords: injury of the hand, treatment, result, children

Травмы кисти у детей и взрослых занимают особое место в структуре повреждений опорно-двигательного аппарата. За двухлетний период было пролечено 70 детей с открытыми травмами кисти. Анализ результатов лечения показывает, что при оперативном лечении открытых травм кисти приоритет должен отдаваться максимальной органосохраняющей тактике. Применение единого подхода при открытых травмах кисти у детей позволяет получить хорошие результаты лечения.

Ключевые слова: травма кисти, лечение, результаты, дети

For citation: Gordienko I. I., Tsap N. A., Sosnovskich A. K., Borisov S. A. TREATMENT OF OPEN INJURIES OF THE HAND IN CHILDREN. Medical News of North Caucasus. 2018;13(3):482-485. DOI - https://doi.org/10.14300/mnnc.2018.13083 
Для цитирования: Гордиенко И. И., Цап Н. А., Сосновских А. К., Борисов С. А. ЛЕЧЕНИЕ ОТКРЫТЫХ ПОВРЕЖДЕНИЙ КИСТИ У ДЕТЕЙ. Медицинский вестник Северного Кавказа. 2018;13(3):482-485.

DOI - https://doi.org/10.14300/mnnc.2018.13083

The injuries of the hand in children and adults take a special place in structure of musculoskeletal system [1]. Their prevalence reaches 30-57\%, and the amputation effects are the causes of disability in $\mathbf{3 0} \%$ of cases. Treatment of open fracture and hand injuries is a very severe problem, because is pursuing aims to not only reach stability and speedy recovery of the integration of the bone structures, but regeneration of soft tissue. Infection of the soft tissues, as a rule, slows down the bone consolidation, and is a significant risk of posttraumatic osteomyelitis [2].

Most of the open hand injuries in children require the inpatient treatment, containing antibacterial therapy which is assigned for too long time what can lead to unwanted sequela such as microbicenosis disorder of the digestive tract and formation of antibiotic resistance in microorganisms $[3,4]$. In adults, the following basic principles of perioperative antibiotic prophylaxis (PAP) are distinguished: administration of the drug taking into account the activity spectrum, , the first administration of an antibiotic should be strictly prior to initiating the intervention to achieve maximum concentration at the time of intervention, the preferred route of administration is intravenous, the duration of the PAP after the operation should not exceed 24 hours [7, 8]. In pediatric practice, perioperative antibiotic prophylaxis is limited by a number of reasons: the age of patients, frequent allergic and toxic reactions to the drug, the high incidence of antibiotic-associated diarrhea, which is especially important in children under 5 years old. That's why the timeliness of assessment of PAP effectiveness in pediatrics surgery has a particular importance [5].

The prevalent view that the prophylactic use of antibiotics reduces the risk of infectious complications in the detachment of distal finger phalanges has been refuted by randomized studies showing that only adequate primary surgical treatment (PST) is sufficient to prevent infection in injuries without severe contamination of the wound, which remains controversial theme [6].

The aim of the work is to study mechanogenesis and types of hand injuries in children, to analyze surgical tactics with various open brush injuries in childhood.

Material and Methods. The selection of the clinical material was made during the period from January 2016 to December 2017, 210 children with various hand injuries were examined and treated, of which 70 (33.3\%) victims had open lesions of different localization (Fig. 1), including with open fractures of phalanges of fingers and metacarpals, $20(28.6 \%)$ children were treated. In the structure of open bruises, traumatic amputations of soft tissues and phalanges of the fingers predominated - $30(42.9 \%)$ children, the number of cases of bruises of various types and localization without damage to bone structures - $19(27.1 \%)$ - slightly less than open fractures, and one $(1.4 \%)$ child had a combined blast injury of the hand.

The age range of children with open hand injuries starts from 10 months and ends with 17 years: 13 children $(18.5 \%)$ under 3 years old were treated, from 4 to 7 years $-21(30.0 \%)$ children, 36 children $(51.5 \%)$ were 8 years old and older. The average age was $7.6 \pm 4.1$ years old. Gender distribution: boys are the risk group - $50(71.4 \%)$, which are more than 2 times than girls $-20(28.6 \%)$.

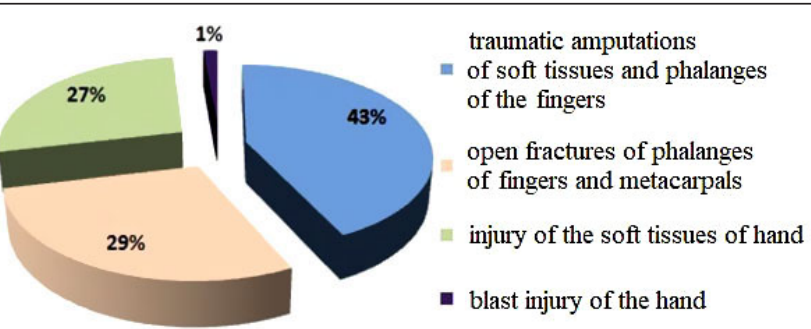

Fig. 1. The structure of open hand injuries in children

Mechanogenesis of open hand injuries in childhood is extremely diverse, but statistical analysis shows the most frequent variants of injuries: $22(31.5 \%)$ children pinched their fingers on the door, $21(30.0 \%)$ children had cut wounds with a knife, 15 children received injuries with broken glass and bottles (21.5\%), 8 children pressed various parts of the hand with heavy objects ( $11.4 \%)$. Single variants of the mechanogenesis of hand injuries are also important. This is due to the complexity and unpredictability of the damage of all anatomical parts of the hand: $2(2.8 \%)$ children were bitten by dogs, in one (1.4\%) case the child shoved his hand into the electric a meat grinder, and in one case $(1.4 \%)$ a firecracker exploded in the child's hands.

All children were hospitalized as a matter of urgency, the radiography of the hand specified the nature of the bone lesions. When diagnosing and forming a clinical diagnosis in 30 patients $(42.8 \%)$ with traumatic amputations of phalanges of fingers and metacarpal bones we used the Allen's classification.

After a short preoperative preparation, under the general anesthesia, the expanded primary surgical treatment of the wound, skin tissue with local tissues and osteosynthesis of the fracture were performed, if the displacement of the fragments was unacceptable (Fig. 2).

Data processing was carried out using basic statistical programs Microsoft Excel, Statistica 6.0 (USA).

Results and Discussion. Among the treated 30 children with traumatic abnormalities of finger phalanges, partial amputation was observed in $12(40.0 \%)$ patients when the distal part of the dissected phalanx was fixed to the finger with a skin graft. In these cases, with the visual viability of the distal part of the phalanx, the replantation of the amputated fragment of the finger was performed and the osteosynthesis of the nail phalanx by the Kirchner wire (Fig. 3 ). The remaining $18(60.0 \%)$ children had complete separation of soft tissues in combination with bone fragments and damage to the nail fold of the distal phalanges of the fingers. With injuries of 1-3 types of Allen's classification and detection of the wound surface in the transverse axis relative to the nail phalanx, cutaneous $V-Y$ plastic was produced with counter triangular flaps on Trankvili-Leali. With amputations of the $4^{\text {th }}$ type of Allen's classification a palm flap on the feeding stem were used, regardless of the angle of amputation. With amputations of types 2 and 3 of Allen's classification and detection of the wound surface in the palmar or dorsal oblique axis of amputation, the palm flap on the feeding leg was also used because of insufficient skin area with the palmar oblique axis of amputation and the risk of excessive stretching of the flap with the back oblique axis of amputation. The nail plate, if preserved, was not removed in all cases, but there were $6(8.5 \%)$ cases of its complete separation from trauma. 


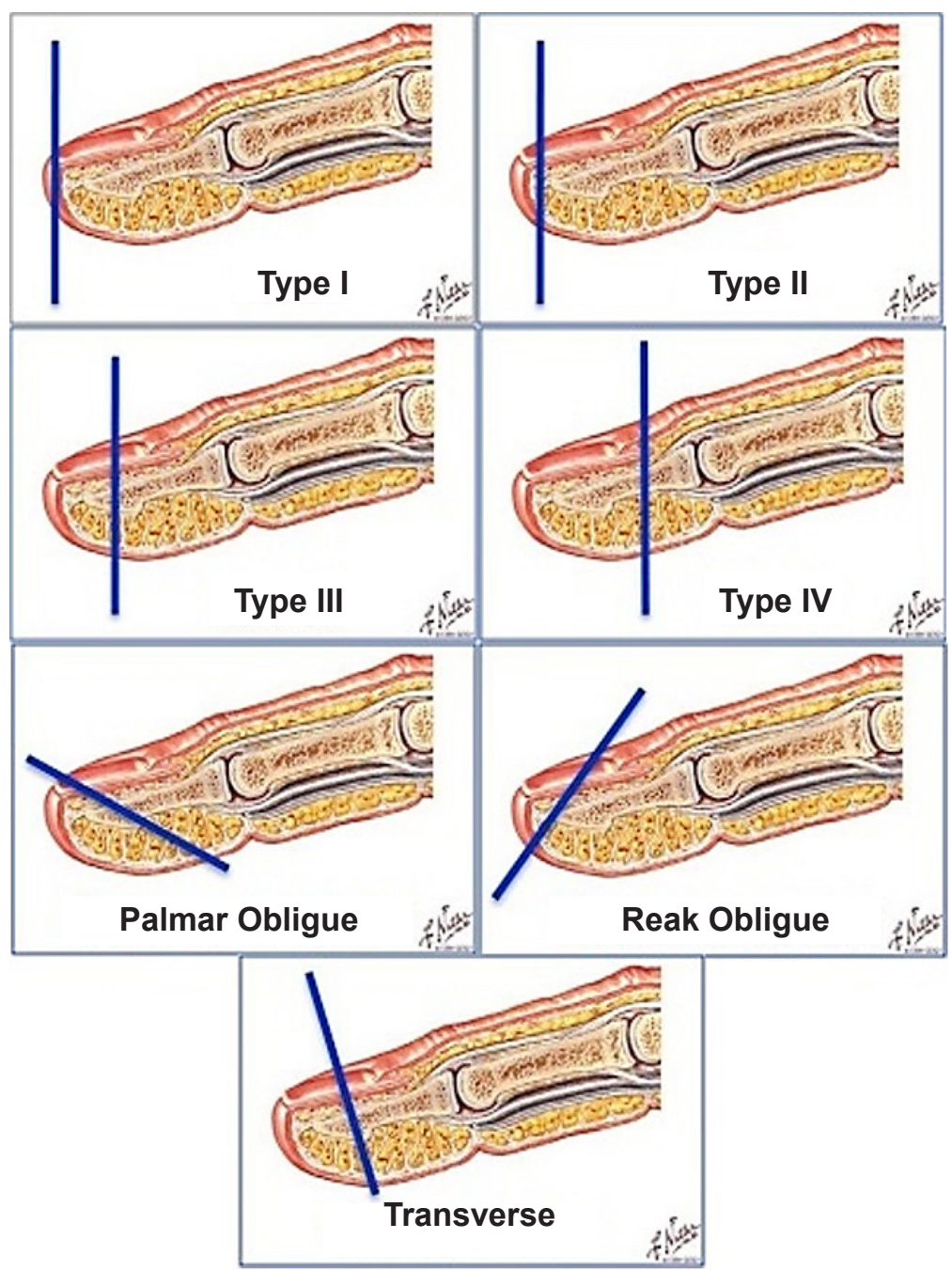

Fig. 2. Allen's classification by the level of amputation and depending on the angle of the line of amputation to the axis of the nail phalanx

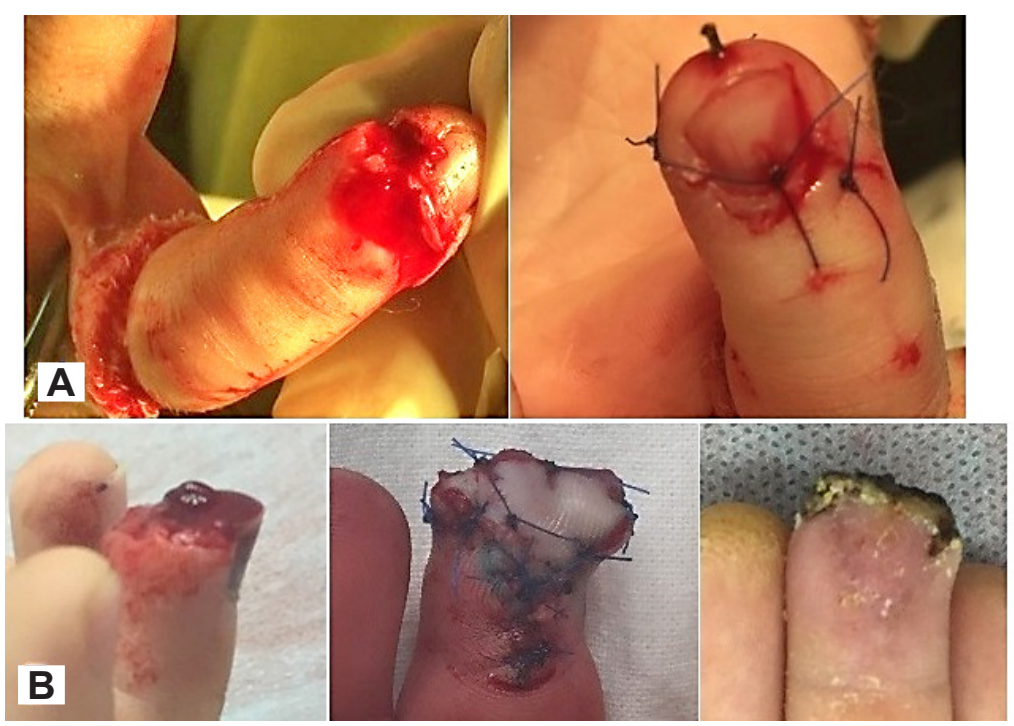

Fig. 3. A - Incomplete traumatic amputation of the nail phalanx of $2^{\mathrm{d}}$ finger of the right hand, type 3 by Allen, followed by re-implantation and osteosynthesis of the nail phalanx with Kirchner's wire.

$B$ - Complete traumatic amputation of soft tissues of the $3^{d}$ finger of the left hand. Type 2 by Allen. V-Y plastic with counter flaps on Trankvili-Leali. Result 1 month after injury
During postoperative period, in addition to anesthesia, children received a course of antibiotic therapy. Predominantly, children received one antibiotic of the cephalosporin group of 1-3 generations. Cefazolin (nacef) was prescribed to $48(68.5 \%)$ children, of whom $43(89,5 \%)$ children received the medication intramuscularly and 5 (10.5\%) patients received intravenously. Cefuroxime (cefurus) received intramuscularly $4(5.7 \%)$ children; cefotaxime (cephalab) intravenously received $8(11.4 \%)$ children. In addition to cephalosporin, 2 (2.8\%) cases were assigned with lincosamide (clindamycin) due to late visit after trauma. Antibiotic therapy was not prescribed in $8(11.4 \%)$ cases, as the size of the wound surface on the hand was insignificant. In individual cases, the antibiotic was administered with premedication $30 \mathrm{mi}-$ nutes prior to surgery or intraoperatively. The average duration of antibiotic therapy with open hand injuries in children was $4.6 \pm 2.0$ days.

In the immediate postoperative period in $2(6.5 \%)$ cases of plastic Trankvili-Leali displaced flap necrosis was observed, due to the violation of its blood supply is damaged when the feed vessel. In the future, against the backdrop of conservative therapy (nicotinic acid intravenously, magnitolazer) indications necrectomy have arisen, the healing was secondary intention under the scab. Also, with plastic grafting on Trankvili-Leali in $4(13.0 \%)$ cases, marginal necrosis of the skin flap was observed, which is associated with a significant tension, but against conservative therapy in the postoperative period, it was possible to avoid necrosis of the entire flap and obtain a good cosmetic and functional result. Unsatisfactory results were not observed.

When plastic amputation of the finger with the palmar horseshoe flap was applied to the feeding stem, good and excellent immediate results were obtained, which enabled the second stage of plastics to be performed in the early period $(3.0 \pm 0.5$ weeks), which consists in crossing the vascular pedicle and the plastics of the fingertip with a patch of the palmar flap. All children's results are rated as good and excellent. In the near postoperative period there were no complications of a purulent-inflammatory nature.

\section{Conclusions}

1. Open hand injuries in children are a medical and social problem, because the treatment tactics of $1 / 3$ of the affected children requires maximum organ preservation and prevention of purulent complications in order to achieve good and excellent anatomical and functional results.

2. The Allen's classification is the most appropriate in the choice of surgical treatment of traumatic lesions of nail phalanxes of fingers.

3. In the operative treatment of open hand injuries and the prescription of perioperative antibiotic therapy, it is necessary to take into account the level, size, contamination of the wound, microcirculatory disorders in damaged tissues, which determines the performance of adequate primary surgical 
treatment of the wound, osteosynthesis in fractures of metacarpal bones, phalanges of fingers and determination of the duration of the course of antibacterial therapy.
4. Posthoc analysis of disease management in the case of open injuries in children allows giving preferences to the perioperative antibiotic prophylaxis.

\title{
Disclosures:
}

The authors declare no conflict of interest.

\section{References}

1. Ekamasova E. A., Voinovsky A. E., Kovalyov A. S., Yusupov I. E., Koltovich P. I. [et al.] Antibiotic prophylaxis of major infections in surgery. Methodical recommendations. M., 2009:22.

2. Zakharova I. N., Berezhnaya I. V., Mumladze E. B. Antibiotic-associated diarrhea in children. M.: Medical Board, 2016;1:78.

3. Kadyrov M. S. Method of choosing surgical treatment for complex injuries of nail phalanges of hand fingers. Reporter of the Kyrgyz-Russian Slavonic University. 2014;14(12):99-102.

4. Malashenko A. A., Aslanov B. I., Detkov V. Yu. Infections in pediatric surgery and the urgency of antibiotic prophylaxis. Preventive and Clinical Medicine. 2016;4(61):32-36.
5. Principles of organization of perioperative antibiotic prophylaxis in health facilities. Federal clinical recommendations. M., 2014:42.

6. Rational antibiotic prophylaxis in traumatology and orthopedics. Informational manual for doctors. Novosibirsk, 2009:19.

7. Uspensky Yu. V., Fominyh Y. A. Antibiotic-associated diarrhea: the urgency of the problem, prevention and therapy. Archive of internal medicine. 2013;2(10):46-53.

8. Allen M. J. Conservative management of fingertip injuries in adults. Hand. 1980;12(3):257-265.

9. Altergott C., Garcia F., Nager A. Pediatric fingertip injuries: do prophylactic antibiotics alter infection rates? Pediatr. Emerg. Care. 2008;(3):148-152.

\begin{abstract}
About authors:
tel.: +79122495480; e-mail: tsapna-ekat@rambler.ru

(c) Group of authors, 2018

UDC 616.71-006.2-007.17-053.2-089.84

DOI - https://doi.org/10.14300/mnnc.2018.13084

ISSN - 2073-8137
\end{abstract}

Gordienko Ivan Ivanovich, Assistant of the department of pediatric surgery; tel.: +79220303337; e-mail: ivan-gordienko@mail.ru

Tsap Natalya Alexandrovna, DMSc, Professor, Head of the department of pediatric surgery;

Sosnovskikh Andrey Konstantinovich, Traumatologist; tel.: +79222174395

Borisov Semen Alexandrovich, Student of pediatric faculty; tel.: +79120421511; e-mail: semka_bard@mail.ru

\section{USE OF FINE-GRAINED TITANIUM NICKELIDE FOR THE TREATMENT OF DYSTROPHIC BONE CYSTS IN CHILDREN}

\author{
Trushin P. V. ${ }^{1}$, Slizovsky G. V. ${ }^{2}$, Shtofin A. S. ${ }^{1}$, Danbaev G. C. ${ }^{2}$ \\ ${ }^{1}$ Novosibirsk State Medical University, Russian Federation \\ 2 Siberian State Medical University, Tomsk, Russian Federation
}

\section{ИСПОАЬЗОВАНИЕ МЕАКОГРАНУАИРОВАННОГО НИКЕАИАА ТИТАНА АЛЯ АЕЧЕНИЯ АИСТРОФИЧЕСКИХ КОСТНЫХ КИСТ У АЕТЕЙ}

\author{
П. В. Трушин ${ }^{1}$, Г. В. САизовский ${ }^{2}$, А. С. Штофин ${ }^{1}$, Г. Ц. Аанбаев ${ }^{2}$ \\ ${ }^{1}$ Новосибирский госУАарственный меАицинский университет, Российская ФеАерация \\ 2 Сибирский госУАवрственный МеАицинский Университет, Томск, \\ Российская ФеАерация
}

Fifty five patients with dystrophic bone cysts were included in the study, where 30 of them underwent an original operation of bone grafting with finely granulated titanium nickelide. Clinical and radiological effectiveness of this method of treatment in the early rehabilitation period and with remote monitoring was demonstrated. The clinical effect was characterized as good in $96.6 \%$ of patients during the observation period. Clinical experience shows that the application of the method of treatment of dystrophic bone cysts through plastics with titanium nickelide granules gives more positive results in comparison with the traditional method.

Keywords: dystrophic bone cysts, titanium nickelide, plastics, children

В исследование включены 55 пациентов с дистрофическими костными кистами (ДКК), из них 30 больным была проведена оригинальная операция пластики костной полости мелкогранулированным никелидом титана. Продемонстрирована клинико-рентгенологическая эффективность данного метода лечения в раннем реабилитационном периоде и при отдаленном наблюдении. Клинический эффект характеризовался как хороший у 96,6 \% больных в 